\title{
The Contemporary City Between Administration and Geomanagement
}

\author{
Păcurar Bogdan-Nicolae ${ }^{A *}$, Surd Vasile ${ }^{B}$ \\ Received: June 2012 | Revised: January 2013 | Accepted: January 2013
}

\begin{abstract}
The city, judged from the perspective of complexity sciences and tackled in a functionalist manner, is seen by many as a living organism, which is a geosystem that tends towards a finality, called sense of existence. Reaching this finality, that acts as an epistemological axis, offers the chance of a new definition for the city and its functions. Starting from this construction, we are faced with several questions: Must today's city be subjected to a sustainable development or must it be geomanaged in the spirit of a sustainable evolution? Does the concept of sustainable development have a future or must it be replaced with sustainable evolution? What is the revolution brought by changing the concept of sustainable development with that of sustainable evolution?

In the substantiation of the leap from development to evolution, we propose the concept of managerial geography, as a new step of the urban management paradigm, offering the openness for establishing a new taxonomy of urban functions, which introduces concepts like: civic functions; vital functions, frontier functions, etc. By applying the taxonomy to the geography of Cluj-Napoca, respectively the taxonomy of the functional tertiary subsystem, we propose new approaches that will lead to the establishment of this new paradigm: urban geomanagement for attaining sustainable evolution.
\end{abstract}

Key words: administration; geomanagement; paradigm; frontier; sustainable development; sustainable evolution; functions.

\section{The city, a 'living organism'}

In the spirit and scope of each science, the city can be defined and understood through different views. A vast perspective, based upon the complexity sciences (Munteanu, 2008), presents the city as a living organism (Saarinen, 1965). It is without a doubt the best suited comparison for the city, since today, when the spirit of human knowledge probes the world in four dimensions, we observe that it appeared and developed similarly to the complexity of a human organism's evolutions.

Surprisingly, as a study object of geography and of other sciences, from which a new branch was born urbanism, the city configured itself as a well defined geosystem only in the last 50 years. Equally surprising is the fact that not even today did urbanists succeed in defining the city and placing it in a comprehensive, synthetical and fully accepted formula. We dare to believe that this 'handicap' was generated and is still maintained by the same philosophy that launched it, the Cartesian philosophy, where everyone embraced it as a material 'construction', in a mechanistic manner. Furthermore, many tried to 'trap' it within mathematical and graphical models, etc.

Therefore, we put forward another perspective on the city, which will be defined as a geosystem, a living organism, which, obviously, like any other geographical system, reaches for finality, reaches for its balance. We view this finality and we call it the attainment of the city's 'sense of existence' ('menire' in Romanian). If we will try to understand and define it, with this finality at its core, we might find a new definition that

\footnotetext{
A Cluj County Council, 106 Dorobanților Street, 400609, Cluj-Napoca, Cluj County, Romania

B Faculty of Geography, Babeş-Bolyai University, 5-7 Clinicilor Street, 400006, Cluj-Napoca, Cluj County, Romania

* Corresponding author: Bogdan-Nicolae Păcurar, e-mail: pacurarbogdan@ymail.com, telephone: 0040746148772.
} 
can be useful, in our opinion, for further research. So, the city is a highly organized geographic space, with a permanent dynamic, capable of ensuring a diversity of functions for its own evolution and development and for the evolution and development of its influence space.

\section{The city, between sustainable development and sustainable evolution}

The postmodern city is a geographic structure of unparalleled complexity in all man-made systems, on its entire anthropological route. However, the history of anthropology emphasizes 'frontier' episodes and époques in which the cities of the time, after becoming true achievements of mankind, were basically wiped out, and civilization had to backtrack and resume the evolutionary cycle on empty ground, losing, sometimes irreparably, ancient accumulations. We will exemplify with a few moments from human culture and civilization: the Etruscan cities and civilization, after reaching a stage that exceeds even some European cities of today, disappeared for good; after the Roman cities, or Byzantium and its urban civilization were swept away by the Christian Revolution, 1000 years were necessary for the Christian European civilization to rebuild the urban forms, only managing to reach the level of fortification or fair town, of urban kernel. Were all these 'threshold moments' the result of 'development' or of 'evolution'?

The processes of today's world frontier, the last step of the European frontier (Bădescu, Dungaciu, 1995), compels us to think more responsibly, in the spirit of a 'global ecology', on the evolution of the contemporary city. But, in this debate, we are constantly bombarded with the notion of sustainable development; when the issue of urbanism is tackled, but also the issues of other geosystems, the specialists innovate, create and prove theories and concepts, which, when applied, raise questions on their future consequences. One of these questions is the following: Must the contemporary city be sustainably developed or must it be managed in the spirit and philosophy of a sustainable evolution? This question, used aporetically in this case, might lead to interesting and revealing reactions and answers, if the issue is tackled in the spirit of 'complexity sciences'. This is done by 'overcoming the limits imposed by the current perception and paradigm' where we unfortunately operate with simplified models through which we 'fall in love' with the created image, with the model (Munteanu, 2008). That is why we consider that, when we study and tackle an urban geosystem, in all its complexity, and opt for its 'development', it is necessary to bear in mind the philosophy of the concepts we use in the analytical equation, it is necessary '...to develop our mind at the level of na- ture's complexity, and not to bring nature at our level of knowledge' (Munteanu, 2008).

To develop (development) is a syntagm that defines a now 'classic' concept and which, in most dictionaries, has the following meanings: 'to pass from an old qualitative state to a new one, from an inferior to a superior level'; 'to extend, taking considerable proportions, gaining strength, growth, to expand' (Mayor, 2002).

The evolution of human society, but most of all the increase in sociosystem complexity, determined by the 'European frontier phenomenon' (Bădescu, Dungaciu, 1995), emphasized some processes of this frontier, which denounced, in an alarming manner, the imbalances created by the economic and social evolution and development in relation to the resources that the natural geosystems can and will be able to provide. Essentially, the socioeconomic development of the last 300 years is based on the Cartesian philosophy and is rested on the 'predator's' philosophy, searching for: the maximun growth of production (agricultural, industrial, financial, etc.) without concerning itself with the balance between it and the natural fundament, the natural environment; man made spatial extension through the destruction of the natural space; removing, to the brink of depletion, resources from the natural space and dumping all the metabolical waste of the 'developed' world in their place, etc.

In this context of searching the answers for which paths to follow in the socioeconomic evolution, the second half of the $20^{\text {th }}$ century saw the launch of concepts such as sustainable development and sustainability, etc. The first major energy crisis (the oil crisis of 1973) opened a period of arduous searches in which the concept of sustainable development was introduced and substantiated with larger or narrower meanings.

The World Commission on Environment and Development established and defined this concept in 1987 as the '...development that meets the needs of the present without compromising the ability of future generations to meet their own needs', while the final establishment as it is known today took place in 1992, at the Rio Summit.

The concept of sustainable development did not succeed, however, in configuring a clear philosophy on the development of society. It opened, on the other hand, several different approaches or perspectives on the subject.

From the perspective of the integrated approach (Rogers, et al., 2008), there are three directions for the concept's philosophy: economic, ecological, and sociocultural. The taxonomical perspective (Willis, 2005) on the approaches tries to order the theories of modernization and development of the last 60 years, while the analytical perspective (based on analytical indexes) (Vădineanu, 1998) groups the approach indexes into 
economic, environmental, social and political indexes. No matter the approach perspective, the researcher will observe, in the literature of the last two decades, that the approaches on the concept of development (sustainable development included) are in balance with other concepts:

1. the growth-development relation was tackled by Redclift (1987), Daly (1997), Meier (2001), Greenwood, Holt (2010) and so on;

2. sustainable development compared to concepts such as human development and equitable development can be found in studies by Rodomonti (2003), Greenwood, Holt (2010), Parodi, et al. (2011), etc.;

3. sustainable development compared with the natural environment's ecology can be discovered in representative studies made by Redclift (1987) and Rogers, et al. (2008);

Even though many approaches strive and aim towards the necessity to change the current lifestyle, most of the sustainable development's philosophy, despite any definitions or sophism on its determinism, is basically a '...conceptual variation on the utilitarian concepts of development and an attempt to synthesize and integrate environmental policies' (Wildes, 1995). It is in fact the same consequence of Cartesian philosophy, although some authors manage to conceptually balance the premises of sustainable development in its substantiation (Mac, 2008) (Figure 1).

Although the approaches, the debates and the confrontations did not succeed in coming up with clear and unanimously accepted conclusions and decisions on the favourable paths to follow (in the spirit of global ecology), the last five decades configured a series of development theories such as: the modernisation theories of the 50's and 6o's; structuralist theories; the neo-malthusian theories of the 7o's; neoliberalism; sustainable development; postdevelopment (Willis, 2005).

But despite the ideological, media, academic and socio-political spaces smitten by it, where sustainable development is still supported, recent voices critique and contest its validity. We mention only a few critical interventions such as Meyercord (2010), who considers this notion of sustainable development as '...so amorphous it almost defies definition', naming it an oxymoron. Likewise, Parodi, et al. (2011) draws attention to the conflictual potential of the concept due to the usage of sustainability as a mere design, as an ideological illusion and as an utopian hope. Hulse (2007) mentions that sustainable development remains under the risk of ignoring the past, the concept being frequently used even when the objectives or assessment criteria are not declared or when it cannot be proven that progress is systematically determined.

These critiques and their fastidious nature come to life from a conscience awakening and are part of an increasing wave of people who wake up and search for an alternative, that feel that we are on the brink of a 'major conscience revolution' (Laszlo, et al., 2003), a conscience that grasps the fact that the main cause of the global crisis is '...our system of values generated by our education to have more without caring how we obtain it, without caring about our fellow men, about the toll on the planet' (Laszlo, et al., 2003).

Here is why, in our modest endeavour (slightly aporetic), we understand that, in holarchically organized geosystems, the main problem of 'development' philosophy still remains: Who, when and how it decides on its limits, on the possible balances and imbalances in a limited and fragile world?

As long as sustainable development philosophy is based on egocentrism, and every idea, thought, plan or strategy puts social prosperity, the qualitative improvement of population wellbeing (Daly, 1997), and the selfish man, at the center of decision making, the results will lead to imbalances and the depletion of holarchic systems. We exemplify this idea with the help of the following figure (Figure 2).

To evolve (evolution), mirroring the concept of development, established by the same dictionaries, generally means 'to pass through a series of transformations, through different progressive phases to a higher level', 'to run its course', etc. We must not neglect the

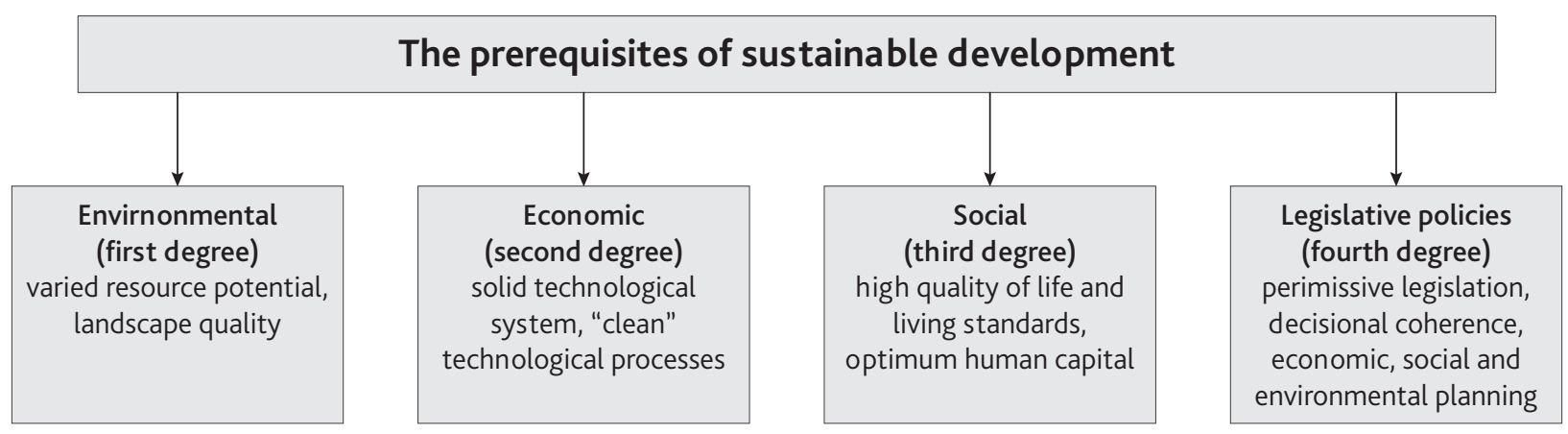

Figure 1. The synthetic scheme of the premises of sustainable development for a given territory. Source: Mac, 2008. 


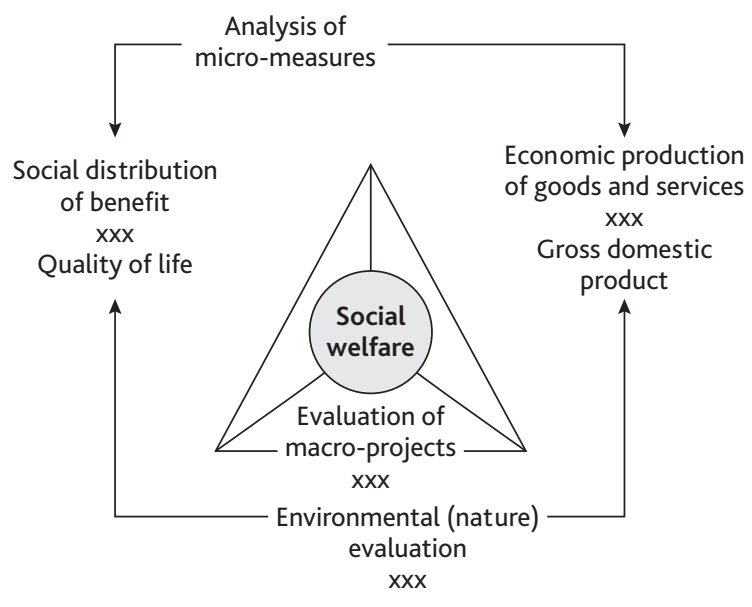

Figure 2. Decisions for sustainable development: criteria and components.

Source: Sadler, 1988, adopted from Mac, 2008.

fact that the philosophy of 'evolution' established, in its ideological space, concepts such as 'the flat evolutionism' (Spencer, 1972), which reduces the process of evolution to mere qualitative accumulations, but also 'emergent evolution' (Alexander, 1920), mostly opposing flat evolutionism.

All these concepts and their definitions have however a substantiation that places evolution within and as a part of development, a consequence of the $20^{\text {th }}$ century dominant system of thought, either predominantly dialectic or predominantly metaphysical.

If we open our minds in the spirit of the above mentioned complexity, we will see here two philosophies with a 'transdifference' space; what we consider crucial in the spirit of the urban geosystem approach is that difference between 'development', where man acts like a god towards the geographical space and 'evolution', in which philosophy imposes 'following a path' in the attainment of that 'sense of existence' (Păcurar, 2011), in which man has the role of supporter, coordinator, harmonizer between natural space and human (artificial) space. In this gnoseological framework, we put forward the concept of sustainable evolution, applicable in our view to the process of urban geosystem management and to the management of all geosystems. We define sustainable evolution as the creative, optimal and harmonious regeneration of holarchically organized geosystems' lives.

The concept of sustainable evolution is therefore seen as an alternative to the concept of development and not as part of the development process. In this manner, a geosystem belonging (mandatory) to a holarchy will function based on those fundamental elements: energy, entropy and information, while an ecological management in a 'hierarchical system' is the way - in our view - towards that creative, optimal and harmonious regeneration. It is the way through which we prevent the concept of that hypostatical sustainable development, created in a linear fashion, to transform the city into a genuine 'predator' for all natural systems and through which its increase, its growth basically becomes a downgrade of other spaces, a 'black hole' in the natural landscape. But to fully comprehend this necessity, this change, we must become aware of the need of change in 'the dominant conscience' (Laszlo, et al., 2003) and of the fact that only through a 'consciousness revolution' can we separate ourselves from the model we 'fell in love with', that is sustainable development.

That is why we believe and support in this context that the contemporary city must sustainably evolve and not be sustainably developed. Only through a evolutionary harmonization of the natural space with the human one can the desired goal be attained, without assaulting nature, without assaulting the past and without compromising the future, our goal, consequently reaching the state defined by Sachs (1978): '... the harmonization of the social and economic objectives with the ecological ends in the spirit of solidarity with future generations ... creating a true man-nature symbiosis'.

\section{The city, between administration and geomanagement}

If in the gnoseological approach, we adopt the definition of today's city, whose 'reason to exist' is to achieve its finalities, the next step of the epistemological critical path generates the question: Will today's city evolve towards the attainment of its finality through administration or through management? The evidence presented by an increasing number of philosophers and scientists, on the reality of life, emphasizes an extraordinary complexity within the current and future geosystems, so extraordinary that we dare to postulate that the only open path towards the city's sustainable evolution is through management.

From a semantic point of view, between the urban administration and urban geomanagement there are transdifferences that many times induce some synonymies in the officially or unofficially expressed mentality. Most of the official documents, and most of the literature on administration, geography, urbanism, etc. speak, in the field of 'territorial systems', about: local administration; administrative functions; the State's administration, etc. However, the same 'world' builds an entire literature on company management; organizational management; quality management, knowledge management etc. Basically, we observe an inversion of meaning, of the concept of management. And we exemplify this with the following question: Why does a microsystem need management, while a 
mezo- or macrosystem can be sustainably developed through administration?

Let us analyze, in our aporetic construction, the above used concepts: administration and management. To administer is to run, to conduct, administration means conducting. Furthermore, administration is an army service whose duty is to feed and equip the troops, while administrator is a person who runs something, administers; who runs an administrative service (Mayor, 2002). The whole semantic family of the verb 'to administer' emphasizes some transdifferences, but also obvious synonymies with 'to run something. The space and level that the concept implies is micro-referential. To administer does not imply anything involving development, growth, evolution, but the correct and efficient control of the state of the administered system.

However, regarding the term 'management', we observe that the dictionaries give the same meaning: the activity or the art of leading; the science of organizing and leading; the ensemble of organizing and leading. Thus, some superior valences emerge from the meaning of management, valences that are non-synonymous with administration: the art of leading; the science of organizing and leadership and so on. Therefore, the concept of 'management' has synonymies with administration, but encompasses superior meanings (to lead, to organize), that all direct to a complete approach framework of a system (urban geosystem), that of the science and art of organization and leadership, based on projects, strategic and tactical objectives.

We therefore state in this 'modest stop' on the subject, that an urban geosystem of high complexity cannot evolve only through administration. Administration is the mission to keep and viably run a condition (of the geosystem). The evolution of a city and especially its sustainable evolution require without a doubt a complex and superior science: geomanagement. We chose this term as the city is a geosystem whose management is based on a geographic territory.

This all the more important as the researcher that studies the concept of 'urban geomanagement' will discover, in several titles, approaches that overlook the geographical (physical) foundation of the urban system (the fundamental element alongside the human element, part of what a geosystem or geographical system is: 'The geosystem is defined by three shares - the elements, the elements' states and the relationships between elements and states' (Mac, 2000). In a study signed by Bačlija (2011), out of seven definitions given to urban management, launched between 1970 and 1998 by the same number of authors, only the one signed by Chakrabarty (1998) makes a clear reference to 'physical resources' and only Mattingly's defi- nition (1994) contains the strategic direction of management (normative, projective and operational).

\section{The position of the managerial geography in the paradigm of the urban geomanagement}

The philosophy of geomanagement emphasizes, within the structural sphere of the urban geosystem, a certain complexity, that no science or domain can exhaustively 'cover'. The city is a complex system that contains in its holarchy (depending on the taxonomy used) three fundamental subsystems: the geographic territory (natural system); man or society and the built-up anthropic space (urban infrastructure). This schematic structuring actually encompasses the city's (geosystem's) 'elements', to which, in order to analyze its structure, according to the general system theory, one must add: 'the state of these elements and the relations between elements and their state' (Mac, 2000). The last two structural parts mostly make up the 'social capital' of the city, in which the 'state' of the elements and of the relations is a true 'barometer' of the system's social balance. If we spatially analyze each of the three great urban subsystems, we will uncover a structural geometric progression, in which the relations and interconnections between elements objectively require sciences and scientific branches in order to explain and understand them: administrative sciences; political sciences; fundamental sciences; social sciences; applied sciences; earth sciences, etc.

In this equation, geography, as a synthetic science, covers a significant part of the urban space. We exemplify this by presenting the following gnoseological construction (Pacione, 2009) regarding urban geography (Figure 3).

This urban complexity has led in the last century or so to the emergence of a 'true science' of settlements and especially of cities called 'urbanism'. Consequently, if we accept the reality of this geosystemic complexity, it is absolutely normal to become aware that each of these sciences or scientific domains, when tackling urban evolution, cannot limit themselves to an ascertaining and descriptive character. The role of each of them is to go beyond the 'normative' level.

The perspective-reflection on this process of 'ascension' of all the sciences and domains to the normative level, within the study of the city, implies a major risk (which actually manifests itself at the moment), that of independent action and approach, parallel and in a uncoordinated form (euphemistically speaking). Then, which of these sciences and domains have the necessary ability and build to assume a coordinating role in the city's geomanagement? Because a healthy, ecological management must be the synergetic ex- 


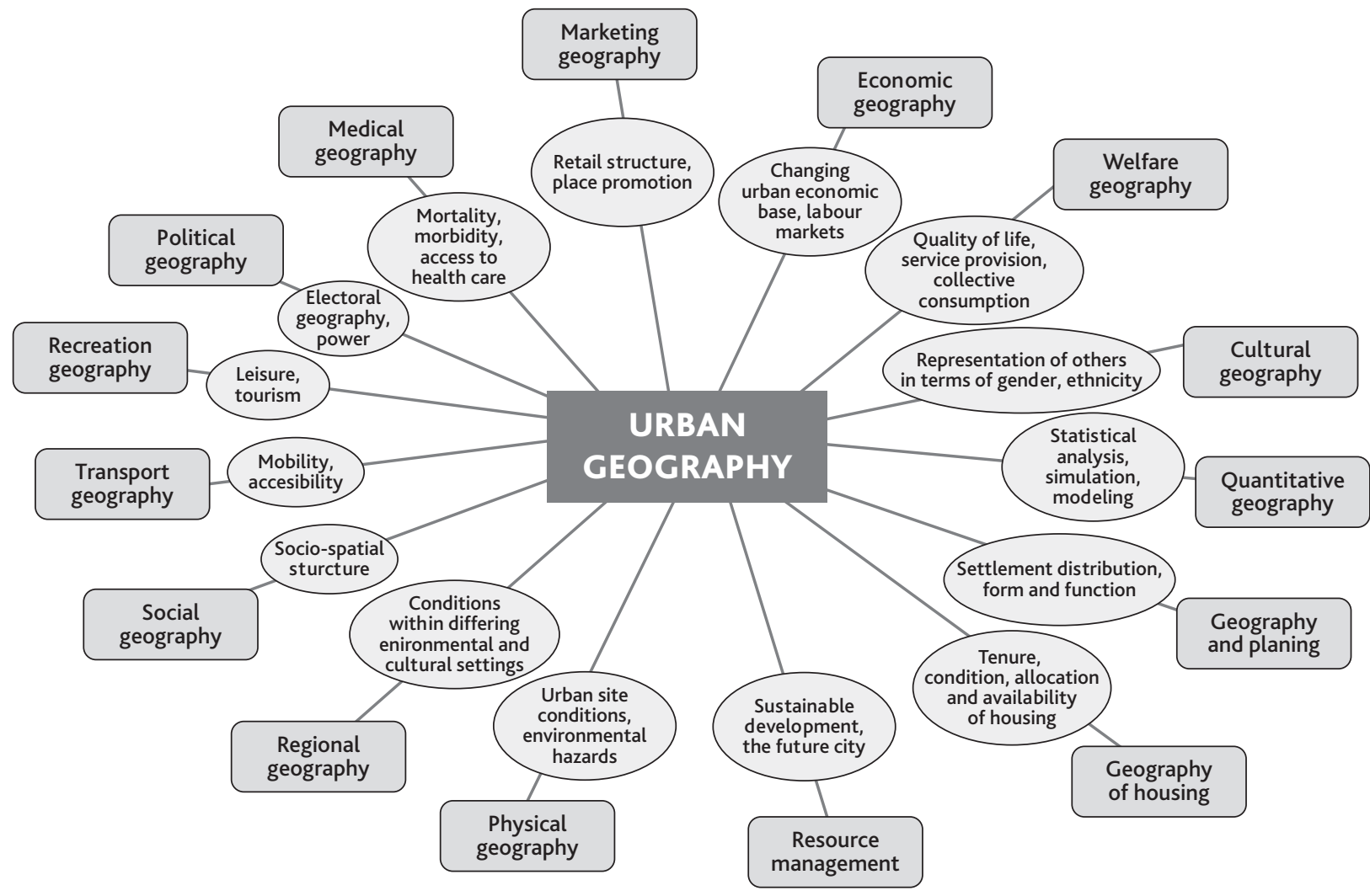

Figure 3. The nature of urban geography

Source: Pacione, 2009

pression of all the participatory sciences, of all factors, that can be objective, but also subjective.

'Complexity sciences' must therefore intervene in this process by using, among other instruments at its disposal, the basic principle of convergent engineering: all efforts towards the attainment of the same target - sustainable evolution.

We view the role of managerial geography in this process as a participatory and possibly coordinating one, but only if the geographic science, having all the necessary tools, will be capable of conceptually restructuring itself in the approach of geographic systems (of territorial systems first of all, but of all geosystems in general). For such an approach, the structure of a geomanagement will have, in our view, the holarchy of a double pyramid of managerial geography (Păcurar, 2011) (Figure 4).

This epistemological construction can be assimilated with a fractal agglutination and it will conceptualize that the geoanthropic space and especially the urban space can harmoniously evolve alongside the natural space, without introducing rationalistically-prospectively modeled solutions in the geographic space, but, through permanent knowledge and normative coordination (prospective, projective, operational), adopting 'natural' solutions, that do not harm the natural space and that harmonize the human space (theoretical, ideological, projective, etc.) with the complexity of life. We will dis- cover here an integration process of all the city's 'spaces', starting from natural simple space (biological, ecological) and ending with the complex ones: social; info-communicational; philosophical, etc., as an expression of the sociosystem's evolution towards superior forms of 'rationally legal, bureaucratic' (Culda, 1999) organization.

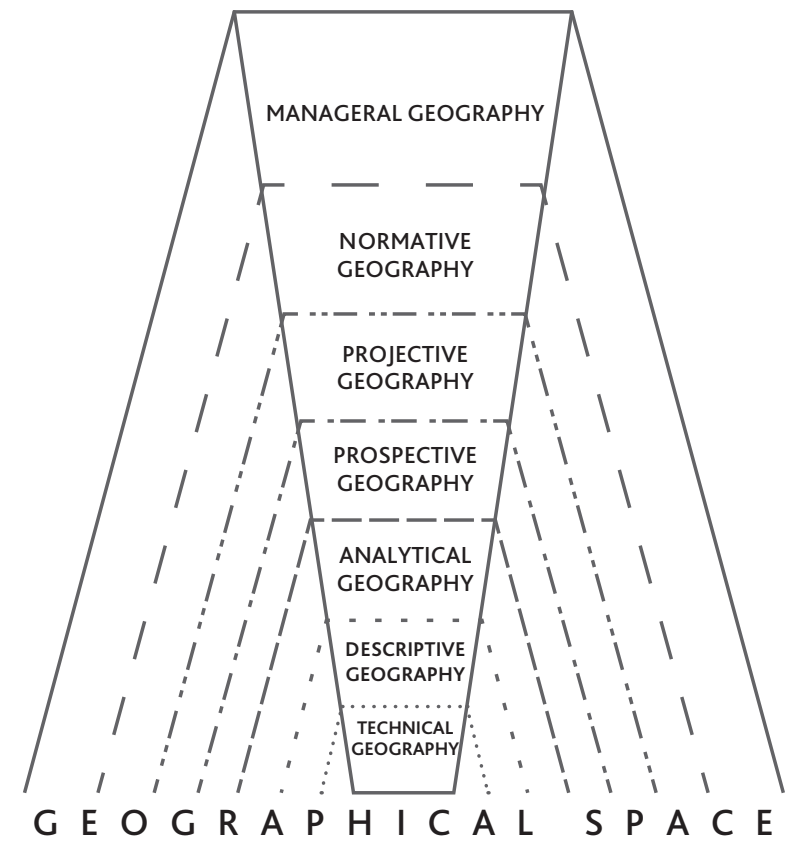

Figure 4. The double pyramid of managerial geography 
In this historical process, the city reaches the level of the self-conscious organization, that went beyond its first objective, 'self-generation and perpetuation' (Culda, 1999). The city is obligated at this level to objectively reconsider its position, but also the role of its 'social intepreters', so that the proportion between those meant for its own existence through self-regeneration, administration and self-control and those for control and command can radically change, starting from a new philosophy which will strengthen its crisis avoidance abilities (abilities of development, legitimacy, competence, etc.) and sustain its ecological selfregeneration, in order to reach the limit of dynamic equilibrium through which it will respond to the 'assumed necessity', basically its sense of existence. We therefore clearly see that the major problem of our days is the harmonious integration of social structures with natural structures and establishing large geosystemic territorial units with balanced evolutions (Mac, 2008).

This integration, through sustainable evolution (and not sustainable development) requires a sinergy of all sciences, a sinergy in which a new concept - that of managerial geography - can catalyze, order and coordinate all the efforts towards the attainment of the same target, urban (total) management.

A properly 'constructed' managerial geography can ensure through total urban (systemic) management the ecological evolution of the city, firstly because it is a synthetic science, that encompasses within its ontological sphere the entire geographic space. It is similar with medicine which, through evolution, gained an impressive array of domains and 'medical sciences', but still remains, at its core, the sole science for the man's health. The same thing happens with geography. It does not matter whether we consider it an Earth science or we call it the science of geographic space and so on, it still remains the only science whose object of study (exhaustively) is the geographic space(s) (natural, man-made, social, political, virtual, etc.). The geosystems of this space can be managed through a 'critical chain', conceptually and projectively, which in our view contains:

1. becoming aware of the states in the geosystem;

2. becoming aware of the tendencies for change;

3. understanding (by knowing) the relations between elements and states;

4. identifying the present and future ratios between the elements of the system (urban, etc.);

5. foreseeing the direction and the ways of evolution: favorable or unfavorable (constraints, obstacles, etc.)

6. determining or the revelation of the evolutionary steps, of evolutionary processes and phenomena, within the system;
7. creating the conception for the support, orientation and harmonization of the evolution;

8. educating the socio-human element, in the spirit of eco-evolution and enrichment of the geosystem's 'social capital';

9. creating and introducing life norms within the geosystem and

10.administrating the evolutionary processes and monitoring systemic reactions, etc.

In conclusion, how, who, under which form and when must it assume the complex role of geosystemic coordination and management? This is the aporetic question! However, in this complex process, nothing can be done without a managerial geography.

\section{The taxonomy of Cluj-Napoca's functions under the projection of the geomanagerial paradigm}

Our entire epistemological endeavor sits under two philosophies: functionalism and complexity science. Following their principles, we see and define the city as a 'territorial system', complexly organized, capable of generating a diversity of functions. In the spirit of the same philosophies, we believe that the city must be considered more than a 'human construction'. In the anthropological relation, each city becomes a 'place' and acquires a spirit of place, has a sense of existence that it desires to reach with the support of its functions. The city's function must therefore be considered separately from the spirit generated by Cartesianism and by the 'European frontier' (Bădescu, Dungaciu, 1995). In our view, the city's function is a necessity relation, that appears between the elements of the urban geosystem and the geosystem's state and which generates, cultivates and sustains the city's life in order to achieve its systemic sense of existence (finality) (Păcurar, 2011).

In this context, the stage of urban management, necessary for a sustainable evolution cannot be attained without appropriating the philosophy that supports this definition and that is based on the concept of city predestination, in opposition with the Cartesian perspective that views the city's function as something that attracts necessary resources (Surd, 2009).

That is why we find a new taxonomy of city functions as objectively necessary, especially when, forced by the structural complexity of it, we introduce other axiological perspectives than those 'sectorial-productive' (services). By building this new taxonomy based on the principle of sense of existence, the taxonomy of a rural or urban settlement will have two basic category of functions: vital functions and conjunctural functions. 
This classification can also solve a problem long avoided by geographers, urban planners, anthropologists, etc., that is the formal consecration, through definition, of the substantiation and classification of rural functions. In this case we would like to briefly mention our belief that the innability to accomplish and reach this goal is fundamentally caused by the tools that have been used in the defintion and study of urban functions. One of the inconsistencies of the General System Theory is quite apparent here: if the theoretical (conceptual) model is wrong or insufficiently substantiated, this will inevitably lead to wrong conclusions. And here is how, by tackling the problem of settlement functions, modeling them (the urban functions) according to theoretical models, tributary to different principles, we found ourselves unable to define rural functions; when it comes to villages, we cannot say that the function is an exerted profession as the village's functions are foremost vital ones, having a role of rural anthropogenesis. This is the reason why we reiterate the definition put forward in 2011 regarding the village's function: the rural function is the village's sinerget$i c$, vital ability to generate, cultivate and sustain its life, in order reach its finality, its sense of existence (Păcurar, 2011).

Returning to the taxonomy based on the concept of sense of existence, we bring forward, in support of it, a 'threshold element': which is the first sense of existence of the city (of any settlement for that matter) that its functions must respond to? The first one is the in surance of the habitat. Regardless of the historical and geoanthropological period, supplying the city with resources by using the habitat function was never done. This function has a vital meaning and only serves the civic aspect of the city, therefore being a civic function, alongside several other vital functions. Consequently, the city's functions will be the following:

1. vital functions (the habitat or residential function; the security function and the religious function); we grouped these three functions in a triad of vital urban functions and

2. situational functions (situational-vital functions and situational functions).

Despite the fact that the main target of this article is the consideration of the relationship between urban management and urban administration, we believe it necessary and justified to minimally substantiate the city's vital functions, with an emphasis on the religious function.

Once the principle of 'sense of existence' is accepted and adopted as a generating principle (starting point) for defining urban functions, the reader will embrace, as natural, the fact that the habitat and security func- tions are vital for the city. Maslow's pyramid model, especially the one set on seven levels (1943), and the human activities model of Geyer (2002) come to support this point of view.

But how do we justify the inclusion of the religious function in this category? We endorse this inclusion with the help of several arguments from philosophy, anthropology and theology. Țuțea (1992), a brilliant philosopher, a supporter of leftist ideas in his youth, stated that 'Man's position is determined by his/her relation to God, the universe, peers and himself/herself'. Here we see the expression of an ancestral string of arguments that prove that for man, as a superior being (as an individual, as an organisation or society), the third vital necessity, after food and shelter (security), is the relation with the divinity, provided by religion.

Most researchers consider that the root of the word religion comes from the Latin 'religio', meaning 'tying together'. Kerze (2006) substantiates this key concept as 'the understanding of the role played by religion within a society' and according to which religion 'ties' together: people in a community; the past with the present, thus building traditions; man with the divinity around a sacred reality, a reality nurtured by the church and through which the human conscience reveals godhood (Vlas, 2008).

In almost every human settlement, the 'institutional logistics' of the man-God relation ('connection' with the transcendental) is supported and nurtured by the religious function. This function holds the settlement's (either urban or rural) community together. Without it, the community would scatter.

Religion's role, and the role of the religious function is '...to give meaning to life in the world, by providing emotional and psychological support and by creating a community' (Vlas, 2008).

Religion was so paramount to human development that it had an urbogenetic role. The study of urban structural models, of history and civilization, proves the crucial role of consecrated cities in the anthropological evolution (Păcurar, 2011). The great religious 'frontiers' (Turner, 1921) built consecrated cities, while the religious function, within urban geography, is an urban-generating function. The institutional logistics of religion in cities or villages today is the expression of the consecrated city at a microreferential scale.

Anthropogeography does not contain in the 6000 year old history of settlements a city that did not have religious structures or functions.

This body of evidence configures and demonstrates, with sufficient persuasion, the statement that the religious function, in a city, is a vital function for reaching that settlement's sense of existence. 
Table 1. The functions of the City of Cluj-Napoca

\begin{tabular}{|c|c|c|c|}
\hline No. & Functions & & \\
\hline \multirow{3}{*}{1.} & \multirow{3}{*}{$\begin{array}{l}\text { Vital } \\
\text { functions }\end{array}$} & \multicolumn{2}{|l|}{ 1.1. The habitat function } \\
\hline & & \multicolumn{2}{|l|}{ 1.2. The security function } \\
\hline & & \multicolumn{2}{|l|}{ 1.3. The religious function } \\
\hline \multirow{33}{*}{2.} & \multirow{33}{*}{$\begin{array}{l}\text { Situational } \\
\text { functions }\end{array}$} & \multicolumn{2}{|l|}{ 2.1. The agricultural function } \\
\hline & & \multicolumn{2}{|l|}{ 2.2. The industrial function } \\
\hline & & \multirow{4}{*}{ 2.3. Civic functions } & 2.3.1. The administrative-civic function \\
\hline & & & 2.3.2. The medical function \\
\hline & & & 2.3.3. The ecological function \\
\hline & & & 2.3.4. The urbanistic function \\
\hline & & \multirow{2}{*}{ 2.4. Administrative-political functions } & 2.4.1. The county administrative -political function \\
\hline & & & 2.4.2. The regional administrative -political function \\
\hline & & \multirow{6}{*}{ 2.5. Cultural functions } & 2.5.1. The mass-educational function \\
\hline & & & 2.5.2. The university function \\
\hline & & & 2.5.3. The cultural-festive function \\
\hline & & & 2.5.4. The cultural-artistic function \\
\hline & & & 2.5.5. The scientific-academic function \\
\hline & & & 2.5.6. The sport function \\
\hline & & \multicolumn{2}{|l|}{ 2.6. The commercial function } \\
\hline & & \multirow{7}{*}{ 2.7. Touristic functions } & 2.7.1. The commercial-touristic function \\
\hline & & & 2.7.2. The festive-touristic function \\
\hline & & & 2.7.3. The medical-touristic function \\
\hline & & & 2.7.4. The business-touristic function \\
\hline & & & 2.7.5. The loisir-touristic function \\
\hline & & & 2.7.6. The religious-touristic function \\
\hline & & & 2.7.7. The educational-touristic function \\
\hline & & \multicolumn{2}{|l|}{ 2.8. The financial function } \\
\hline & & \multicolumn{2}{|l|}{ 2.9. The judicial function } \\
\hline & & \multirow{5}{*}{ 2.10. Transport-vehiculatory functions } & 2.10.1. The road-transport function \\
\hline & & & 2.10.2. The rail-transport function \\
\hline & & & 2.10.3. The air-transport function \\
\hline & & & 2.10.4. The inner-urban transport function \\
\hline & & & 2.10.5. The special transports function \\
\hline & & \multicolumn{2}{|l|}{ 2.11. The info-communicational function } \\
\hline & & \multicolumn{2}{|l|}{ 2.12. The military function } \\
\hline & & \multicolumn{2}{|l|}{ 2.13. The info-creative function } \\
\hline & & \multicolumn{2}{|l|}{ 2.14. The frontier function } \\
\hline
\end{tabular}

Once we clarified the taxonomical choice of urban function, we can operate with different functional-urban classification criteria. However, they cannot alter the conceptual foundation of the function's taxonomy and definition. The approach philosophy, the gnoseological concept and the taxonomical principle remain crucial.

In this epistemological concept, we put forward, as a case study, the following taxonomy for the functions of the City of Cluj-Napoca (Table 1).

One might observe that, in our taxonomy, the administrative functions of Cluj-Napoca are classified into two categories: the administrative civic function, part of the civic functions, and the administrative-political functions (county and regional).

\section{The administrative-civic function}

Within the taxonomical construction of urban functions, we proposed and substantiated the category of civic functions. In connection to the definition of the urban function that we put forward, the administrative-civic function receives fundamentally systemic roles and positions. It plays the command role in 
a 'fleet' type organisation, being capable of sustaining the autonomous management of the 'ship' (the city), for a short period at least. Moreover, on the basis of the same management principle, the city, supported by its functions, is capable of acting and evolving according to the 'fleet principle', just like a ship from a fleet that can act in an integrated way or independently. But even when it functions in an integrated manner, holarchically, the city (the ship from the fleet) always has a functional autonomy. This autonomy is 'given' to the city by the administrative-civic function.

It is obvious that the administrative-civic function objectively is awarded a series of qualities, thus becoming a true 'super function', similar to the ecological function and even beyond that. The great complexity and the way in which it influences the city's geography can be seen from an functional-systemic analysis.

The administrative-civic function, within its own subsystem, has the following defining features:

1. it is the (civic) expression, at a micro-spatial level, of the administrative-political function of the oversystems in which the city is integrated into;

2. the administration of the geographic (urban) space encompasses the entire series of functional-systemic domains: the administration of natural space; the administration of anthropic space; systemic security; economic and financial management, etc.;

3. it is the function that catalyzes the principles of 'convergent engineering', in order to attain the city's sense of existence: '....all efforts towards the attainment of the same target' (Mihalache, 1994);

4. it engulfs in its own subsystem or interacts in its approach with the structural-systemic elements and states of all the other urban functions and

5. the administrative-civic functions is perennial; it is the third necessary function, after the residential and the security ones, to consolidate an urban structure; it is actually generated and organized from the first moments of an urban settlement, it grows and perfects itself alongside the residential function, the security function and so on and later completes the geography built by them.

Even though it does not appear in the classifications of urban functions, this function is a historical one. From this point of view, urban geography, urban administration, reveals different forms of manifestation for it in relation to the administrative-political function. Between the two of them, anthropogeography observes: autonomous relations; relations of independence; tutelary relations and democratic relations.

The geography of urban history and the history of administration emphasize that these relations did not follow an optimum evolutionary course, but a very winding path. There are examples of systemic positions even independence between cities and between the states or state structures that contained these cities in ancient times, as well as centralized tutelary positions in the $19^{\text {th }}-2 \mathrm{O}^{\text {th }}$ centuries. The determining geographic factor in this matter has always been the amount of resources that the city had or has at the moment. Maybe this is the main reason why geography consecrated the resource, 'the ability to attract resources' (Surd, 2009), as a fundamental factor in defining urban functions, according to which functions were considered either basic (external) or non-basic (internal).

In some geographic-urban studies, which deal with the issue of settlement administration, this function is viewed as a public act (public administration). In other studies, however, public administration is contested for its manipulative spirit, due to bad historical experiences, in which democracy (but also autocracy) wanted to use public action for the benefit of the leaders.

However, the spirit of the concept of administrativecivic function, proposed by us, is filled with the content and interaction of the public act, institutionally programmed, assumed and organized, for the management of the urban geosystem. Through legiferation, organisation and geographic management, the institutional logistics necessary for the evolution of an urban geosystem is built, a logistics meant to sustain and apply in daily practice, the task given by the public authority, that of administrating the city, that of constructively and publicly expressing the power of organization, projection, taxation and adjustment of the entire system's behavior. This 'power', which the ruling authority of the system is invested with, is objectively necessary, because in a sociosystem, especially in a complex and highly anthropic one, individuals cannot be allowed to decide independently, in any domain (with small exceptions, that do not fall in the category of public act). This authority is in the end the expression of the urban geosystem's self-organization. Even the processes of 'outsourcing' administrative activities of the city (water, energy, fuel supply, etc.) are consequences of a deliberate act, decided upon according to a managerial act.

In this manner or under different forms, the administration of the city is conducted, while the subsystem organized and built for this configures the administrative-civic function. The name of the concept is justified, in short, by the fact that regardless of the oversystems' political organization, regardless of the political and ideological institutions situated or introduced in the city, it must administer itself apolitically, civically, in the spirit and in order to reach a normal and harmonious life in the city. 
In an urban geosystem, there are a series of systemic or oversystemic elements whose role is to administer oversystemic or holarchic spaces. Most of them or almost all of them, being subsystems and parts of oversystems, also contain elements of the policies of higher systems in their structures. In a man-made urban geosystem, therefore in ClujNapoca as well, the only functional subsystem that can be considered as civic, in the sense given by us in the gnoseological substantiation, is that of local administration.

The subsystemic-functional elements of the administrative-civic function of Cluj-Napoca are the City of Cluj-Napoca City Hall (Mayor's Office) and the ClujNapoca City (Local) Council.

\section{The administrative-political functions}

The administrative-political function is an institutional expression of the superior organization of human geospatial structures. Its geographic character is historical and had multiple geopolitical forms, depending on the historical character of human society organization. Its emergence within the city's functional-systemic structure '...is the result of a prior thought, of disputes and rivalries, of a need to serve the region' (Surd, 2009). In previous approaches, as long as the concept is defined through the sintagm(s) of administrative and political function, politicaladministrative function and so on, which is due, in our opinion, to taxonomic-generalizing principles, the wording is justified and covers all loose ends. In the situation at hand, by placing the administrative character of the settlement in the category of civicurban functions, the administrative-political part remains as a separate class and can be systemically analyzed only at levels superior to the city: county; development region; country (state) and international organizations.

The administrative-political function can climb or descend to different geosystemic levels depending on the administrative-political organization of the state or state superstructure. In the case of Romania, the administrative-political function of a city is distributed and decided upon depending on the administrative-political organization at territorial level: county; regional and euro-regional. In contrast to the administrative-civic function, these functions are primordially determined by state policies and not by the city. There are superstatal or international geosystems in which the city can receive (not acquire, which has an objective-geographic determination) administrative-political functions (Brussels, Strasbourg, Luxembourg, Washington D.C., etc.). Here is why we support and propose this taxonomical differentiation of administrative functions in civic and political.
The administrative function enters the domain of politics only when we analyze holarchies that are superior to the city, by consciously introducing the urban settlement, with all its structures and interests, in a hierarchy that involves domination and obligations. From here on, by accepting this status, the function can become administrative-political, through the domination exerted by the higher hierarchical part (the political oversystem) on the civic one. In this manner, the concepts of administrativepolitical function and administrative-civic function are differentiated.

The importance and role of the administrative-political function, for the cities that play the role of centers of development regions in Romania, seems to be a very high 'stake' in the field of regional geopolitics of Romania. Many factors (political, economic, geopolitical and sometimes ethnopolitical) exert on the planning and on the territorial-administrative development of Romania a series of local, regional and even international pressures, with dangerous repercussions on the capacity and sovereignty of the Romanian State. In this moment, it is important, within the administrative-political substantiation and preservation at regional level, that the State 'take care of the tranquility, order...to fix the controversies regarding the interpretation of laws, to impose the abiding of agreements, to promote competitiveness...' (Friedman, 1971). Will the present day Romanian State succeed in doing this in a period when '... it is very hard... to be Romanian' (Țuțea, 1992), when in the politicaladministrative geography 'there is no decision making regarding projects...not to mention vision for its future', when 'No one is responsible for anything' (Marga, 2009), when we clearly see that in today's Romania what lacks most of all and costs immensely is the competence of the administration, as well as morality, character and patriotism?

Political geography will ascertain and register the consequences of these sociosystemic states, which definitely also have implications on the administrativepolitical functions of the city. It is important that the present day state of geosystems (political, economic, social, though, etc.) to find a new footing, otherwise there is the social danger of losing faith in the sociosystems' functions, the danger of destructuring society by losing faith in public administration (branch of the national authorities' activities, either county or local) and perceiving it as manipulation. A study that is eloquent for this situation is the one conducted in 1991 by Simon, Smithburg and Thompson, who, through an exercise of conception, emphasized the fact that in the social and political geography of a community, of a system, where there is no balance between the purposes of the administrative-political organisms and 
the social masses, the dignity of the individual is violated. That is why, according to the authors, an administrative-political function or just administrativecivic must ensure the necessary synergy so that, by 'attaining the administrative-political purpose', everyone wins.

The administrative-political function is therefore an extremely social one, whose actions make urban and regional geosystems become very sensitive. Its systemic importance is highly obvious, and the sociosystemic character is much consolidated. This phenomenon is ever more apparent for an urban geosystem like that of Cluj-Napoca, so complex and with such dynamic positions, functions and roles, especially within the active frontier phenomenon from the Romanian geographic space.

The elements of the county administrative-political function of Cluj-Napoca are those institutions that transpose, in the political-administrative territory of the county, the policies of the Romanian State, coordinated and managed by the Romanian Government. These institutions are: Cluj County Council; the Institution of Cluj County's Prefect; other institutions of the State and decentralized services of the Romanian Government.

The structural support of the above mentioned function is carried out by the two fundamental institutions of the county administrative-political system, Cluj County Council and the Institution of Cluj County's Prefect. The other elements also contribute to the systemic construction from the point of view of function backing, but they are elements of higher, national holarchic systems.

The construction of the regional administrative-political function, where the geosystem of Cluj-Napoca is 'centre stage', is based on several systemic elements, the most important being the North-West Regional Development Agency and the Council for Regional Development.

\section{The role of the new taxonomy / taxonomies}

We see that the functionalist approach regarding the geosystem, having the sense of existence as a functional taxonomical principle, not only brings new classifications, but also new functions and new concepts such as: vital functions; conjunctural functions; civic functions; frontier functions, etc.

Of course, one can ask: What is the purpose of this new taxonomy? We uphold that these new concepts, this new classification, is the expression of the axiology through which we judge the city as a living organism, a complex space capable of generating its functions as a sensitivity reaction to disruptive stimuli, functions that serve its evolution and the evolution of the surrounding geographic space. These functions will mainly serve the city, ensuring the security of the community, ensuring and cultivating the health of the human factor, of the environment and of the systemic structural relations.

When we ascertain these functions, we foremost see them as foundations of the city from anthropo-social, structural and civic points of view and only later do we consider them as bringers of resources. Fundamentally, they must protect the safety of the city, must contribute to the spiritual, physical and moral health, in conclusion, must ensure the life of the city. That is why we call them civic. They are vital for it, without accumulating, only ensuring. They are functions of systemic security and systemic administration.

\section{Conclusions}

Our endeavor and the hypotheses introduced or resulted from it can be concluded with the following:

1. the complexity of the urban geosystem and its evolutive dynamic impose new paradigms for analysis and prospecting its future;

2. these paradigms must start from the rejection of linear, Cartesian models, and must start looking for others, on the basis of a new philosophy of harmonious evolution;

3. urban evolution is a concept that we propose in the spirit of this philosophy with the role of changing the system of thought regarding the city;

4. however, urban evolution, in our view, is a process too complex to be based on the concepts of the current sustainable development; between the two concepts there are connections, but also unsolvable disconnections: How do we 'develop' the city? By submitting the space, by transforming and processing the systemic elements? By placing the human element as first and sole beneficiary? Or by building a new system of thought and knowledge where all the geosystems' elements can have equal chances?

5. in such a paradigm, can administration (the administrative function) handle the threshold moment or is it necessary for a new level of management? and

6. which is the optimal relation between the sciences and scientific domains encompassed by urbanism, for a healthy future of the city as a geosystem?

The aporetics of our approach and especially of the conclusions are determined by knowing the fact that novelty and accepting some concepts, sometimes, '... is a barrier too easily assimilated' by an 'enthusiast that has the openness, but not yet the necessary base, to truly contribute to the structure of the new vision' (Munteanu, 2008). 


\section{References}

Alexander, S. 1920. Space, Time, and Deity: The Gifford Lectures at Glasgow Part One, reprinted 2004 by Kessinger Publishing, Whitefish, 396 pp.

Bačlija, I. 2011. Urban management in a European context. Urbani izziv (Urban challenge) 22, 2, 137-146.

Bădescu, I., Dungaciu, D. 1995. Frontier Sociology and Geopolitics. Editura Floarea Albastră, Bucureşti, 710 pp. (in Romanian)

Culda, L. 1999. The Sociology of Organisations. Editura Licorna, Bucureşti, 400 pp. (in Romanian)

Daly, H.E. 1997. Beyond Growth. The Economics of Sustainable Development. Beacon Press, Boston, 264 pp.

Friedman, J. 1971. A Non-Cooperative Equilibrium for Supergames. Review of Economic Studies 378, 1, 1-12.

Geyer, H.S. 2002. (ed.) International Handbook of Urban Systems. Studies of Urbanization and Migration in Advanced and Developing Countries. Edward Elgar Publishing Limited, Cheltenham, 610 pp.

Greenwood, D.T, Holt, R.P.F. 2010. Local Economic Development in the $21^{\text {st }}$ Century. Quality of Life and Sustainability, M.E. Sharpe, Inc., New York, 215 pp.

Hulse, J.H. 2007. Sustainable Development at Risk. Ignoring the Past. Cambridge University Press India Pvt. Ltd., New Dehli, 350 pp.

Kerze, M. 2006. The Role of Religion in the $21^{\text {st }}$ Century. http://www.livingdharma.org /MemorableSermons/Kerze-RoleOfReligion.html.

Laszlo, E., Grof, S., Russell, P. 2003. The Consciousness Revolution. $2^{\text {nd }}$ Edition, Elf Rock Productions, Las Vegas, 322 pp.

Mac, I. 200o. General Geography. Editura Europontic, Cluj-Napoca, 542 pp. (in Romanian)

Mac, I. 2008. Normative Geography. Presa Universitară Clujeană, Cluj-Napoca, 413 pp. (in Romanian).

Marga, A. 2009. Crisis and After Crisis. Editura Eikon, Cluj-Napoca, 153 pp. (in Romanian).

Maslow, A. 1943. A Theory of Human Motivation. Psychological Review 50, 4.

Mayor, M. (chief ed.) 2002. Macmillan English Dictionary for Advanced Readers. International Student Edition, Macmillan Publications, Oxford, 1691 pp.

Meier, G.M. 2001. Introduction. Ideas for Development, in Frontiers of Development Economics. Future in Perspective, Meier G.M. \& Stiglitz, J.E. (eds.), World Bank Publications, Oxford University Press, New York, 1-12.

Meyercord, K. 2010. "Sustainable Development": An Oxymoron?. www.zerogrowth.org/sustaindev.html.

Mihalache, A. 1994. The Risk of Decline. EDP, Seria Akademos, Bucureşti, 250 pp. (in Romanian)
Munteanu, F. 2008. Complexity Science and Sustainable Development in the $3^{\text {rd }}$ Millennium. Openings towards the World of Complexity, Editura Universității Bucureşti, 320 pp. (in Romanian)

Pacione, M. 2009. Urban Geography: A Global Perspective. Routledge, New York, 703 pp.

Păcurar, B.N. 2011. The Tertiary Functions of the City of Cluj-Napoca. Presa Universitară Clujeană, ClujNapoca, 456 pp. (in Romanian)

Parodi, O., Ayestaran, I., Banse, G. (eds.) 2011. Sustainable Development - Relationships to Culture, Knowledge and Ethics. KIT Scientific Publishing, Karlsruhe, 228 pp.

Redclift, M.R. 1987. Sustainable Development. Exploring the Contradictions. Methuen \& Co. Ltd., London, $221 \mathrm{pp}$.

Rodomonti, I. 2003. Sustainable, human and equitable development. New perspectives for global trade unionism, presentation at the World Federation of Industry Workers Seminar, Buenos Aires.

Rogers, P.P, Jalal, K.F., Boyd, J.B. 2008. An Introduction to Sustainable Development. Earthscan, London, 416 pp.

Saarinen, E. 1965. The City. Its Growth, its Decay, its Future. M.I.T. Press, Cambridge, 380 pp.

Sachs, I. 1978. Eco-development Strategy. Les Editions Ouvriers, Paris, 260 pp. (in French)

Simon, H.A., Smithburg, D.W., Thompson, V.A. 1991. Public Administration. Transaction Publishers, New Brunswick, 299 pp.

Spencer, H. 1972. Herbert Spencer on Social Evolution. Heritage of Sociology Series, edited by Peel, J.D.Y, University of Chicago Press, $328 \mathrm{pp}$.

Surd, V. 2009. Geography of Settlements. Presa Universitară Clujeană, Cluj-Napoca, 250 pp.

Turner, F.J. 1921. The Frontier in American History. Henry Holt \& Co., New York, 375 pp.

Țuțea, P. 1992. Between God and my People. Fundația Anastasia, Editura Arta Grafică, Bucureşti, 280 pp. (in Romanian)

United Nations World Commission on Environment and Development. 1987. Our Common Future, Oxford University Press, Oxford, 383 pp.

Vădineanu, A. 1998. Sustainable Development. Theory and Practice. Editura Universității din Bucureşti, Bucureşti, 211 pp. (in Romanian)

Vlas, N. 2008. Globalization and Religion at the Beginning of the $21^{\text {st }}$ Century. Presa Universitară Clujeană, Cluj-Napoca, 340 pp. (in Romanian)

Wildes, F.T. 1995. Recent Themes in Conservation Philosophy and Policy in The United States. Environmental Conservation 22, 2, 25-34.

Willis, K. 2005. Theories and Practices of Development. Routledge, New York, 269 pp. 